\title{
Thoughts On A New Draft Bill On Living Will
}

\author{
Padmaja Kanchi ${ }^{1}$, Subodh Kanchi ${ }^{2}$ \\ ${ }^{1}$ Associate Professor, Department of Community Medicine, Terna Medical College \& TSHRC, Nerul, \\ Navi Mumbai, Maharashtra. \\ ${ }^{2}$ Consulting Physician, Mumbai.
}

Corresponding Author: Padmaja Kanchi

Email:padma202@yahoo.co.in; padmamddph@gmail.com

\begin{abstract}
Introduction: As advancement of life expectancy in years is occurring, people are living long life. Most of them need life support for terminal illness at the end of life. Many of them do not wish to continue sufferings of vegetative life \& would like to terminate or discontinue the life support machines or medicines.

Factual Situation: A living will - also known as an advance directive - is a legal document that specifies whether or not you want to be kept on life support if you become terminally ill. 2It permits individual to authenticate their wishes in a written form so that these can be carried out if the relevant situation arises. In addition to the living will, one can select a health-care proxy or healthcare power of attorney who is allowed to make decisions for him or her if he or she is incapable of making those choices.

FAQs on Living Will: Who can make a Living Will? An adult with a sound and healthy mind. What it should contain? The circumstances in which medical treatment should be withheld or withdrawn. It should specify that the Will can be revoked any time. How to Create a Living Will? Many people hire a lawyer to prepare their living will. Most people can create this simple document - along with the other typical estate planning documents - without the high legal fees by using a quality software application that accounts for their state's laws.

Make Your Own Will: You can create a legally binding health care directive (living will) without paying an attorney by using reputable estate planning software, like Nolo's award winning Will Maker Plus. It should give the name of the "guardian or close relative" who will give the go-ahead for starting the procedure of passive euthanasia. The Will shall be attested by two independent witnesses and preferably counter-signed by the Judicial Magistrate First Class (JMFC) assigned the jurisdiction by the District Court. The JMFC shall preserve one hard copy, along with one in the digital format, in his office. JMFC shall forward a copy of the Will to the Registry of the District Court JMFC shall inform the immediate family of the executor, if not informed. A copy will be handed over to an official in the local government or municipal corporation or panchayat concerned. This authority shall nominate a custodian for the Living Will.7

Scenario in India: The Supreme Court has given a landmark decision on 7th March, 2018 on Living Will as per Section $11 \mathrm{C}$. It has confirmed the right to a dignified death as a part of the right to life under article 21 section 11 of the Indian Constitution. The Supreme Court passed a judgment upholding the legality of withholding or withdrawing life-saving medical treatment from terminally ill patients. Families are pushed into poverty tending to the out of pocket expenses of life support.
\end{abstract}

Key words: living will, euthanasia, assisted suicide 


\section{INTRODUCTION}

As advancement of life expectancy in years, people are living longer life. Most of them need life support for terminal illness. Many of them do not wish to continue sufferings of vegetative life \& would like to terminate or discontinue the life support machines or medicines. In accordance, the Supreme Court has allowed individuals to create a 'living will', which will permit medical professionals to withdraw life-support systems under certain circumstances.

A living will - also known as an advance directive - is a legal document that specifies the type of medical care that an individual does or does not want in the event he or she is unable to communicate his or her wishes. [1]

It is a legal document that specifies whether or not you want to be kept on life support if you become terminally ill and will die shortly without life support, or fall into a persistent vegetative state. [2] It permits individual to authenticate their wishes in a written form so that these can be carried out if the relevant situation arises. In many countries, Advance Directives are legally valid and enforceable; they reduce the use of life-sustaining treatments, which often merely prolong life without improving or even maintaining the same level of health. [3]

In addition to the living will, one can select a health-care proxy or health-care power of attorney who is allowed to make decisions for him or her if he or she is incapable of making those choices. [4]

\section{Types of Euthanasia}

\section{Active versus Passive euthanasia}

"Active euthanasia" is taking specific steps to cause the patient's death, such as injecting the patient with poison. In practice, this is usually an overdose of pain-killers or sleeping pills.

"Passive euthanasia" is usually defined as withdrawing medical treatment with the deliberate intention of causing the patient's death. For example, if a patient requires kidney dialysis to survive, and the doctors disconnect the dialysis machine, the patient will presumably die fairly soon. Perhaps, the classic example of passive euthanasia is a "do not resuscitate order". Normally if a patient has a heart attack or similar sudden interruption in life functions, staff will attempt to revive them. If they make no such efforts but simply stand and watch as the patient dies, this is passive euthanasia. [5] In other words, the difference between "active" "passive" is that in active euthanasia, something is done to end the patient's life; in passive euthanasia, something is not done that would have preserved the patient's life. The moral difference between killing and letting die. Many people make a moral distinction between active and passive euthanasia. They think that it is acceptable to withhold treatment and allow a patient to die, but that it is never acceptable to kill a patient by a deliberate act. [6] An important idea behind this distinction is that in "passive euthanasia" the doctors are not actively killing anyone, they are simply not saving him.

\section{Voluntary vs Involuntary}

"Voluntary euthanasia" is when the patient requests that action be taken to end his life, or that life-saving treatment be stopped, with full knowledge that this will lead to his death.79 "Involuntary euthanasia" is when a patient's life is ended without the patient's knowledge and consent. It usually means that the patient is unconscious, unable to communicate, or is too sick and weak to be aware of what is happening or to take any action on his own behalf. [7]

\section{The Aruna Shanbaug case which changed euthanasia laws in India}

\section{A landmark verdict}

The Supreme Court on March 9 ruled that individuals had a right to die with dignity, allowing passive euthanasia with guidelines. The need to change euthanasia laws was triggered by the famous Aruna Shanbaug case. The top court in 2011 had recognised passive euthanasia in Aruna 
Shanbaug case by which it had permitted withdrawal of life-sustaining treatment from patients not in a position to make an informed decision.

\section{The attack}

Aruna Ramchandra Shanbaug was a nurse in the King Edwards Memorial Hospital in Mumbai. In November 1973, she was assaulted by ward boy, Sohanlal Bhartha Valmiki, of the same hospital while changing her clothes in the hospital basement. Valmiki strangulated Shanbaug with a dog chain around her neck.

\section{Living in a coma}

The attack cut off oxygen supply from her brain leaving her blind, deaf, paralysed and in a vegetative state for the next 42 years. From the day of the assault till the day she died on May 18, 2015, Aruna could only survive on mashed food. She could not move her hands or legs, could not talk or perform the basic functions of a human being.

\section{What happened to Valmiki}

In 1974, Valmiki was charged with attempted murder and for robbing Aruna's earrings, but not for rape. The police did not take in account that she was sodomized. A trial court sentenced Valmiki seven years imprisonment. This was reduced to six years because he had already served a year in lock up. Valmiki walked out of jail in 1980 and still claims he did not rape Shanbaug.

\section{Facing opposition}

The Supreme Court accepted the petition and constituted a medical board to report back on Aruna's health and medical condition. The medical board, comprising three eminent doctors, reported that the patient was not brain dead and responded to some situations in her own way. They felt that there was no need for euthanasia in the case. The staff at KEM Hospital and the Bombay Municipal Corporation filed their counter-petitions in the case, opposing euthanasia for Aruna. The nurses at KEM Hospital were quite happy to look after the patient and they had been doing that for years before petitioner Pinky Virani emerged on the scene.

\section{Finally, at peace}

On May 18, 2015, Shanbaug then 66, died of severe pneumonia. She was on ventilator support in KEM's acute care unit. [8]

\section{Countries where active euthanasia is legal}

As of March 2018, human euthanasia is legal in the Netherlands, Belgium, Colombia, Luxembourg,Canada and India. Assisted suicide is legal in Switzerland, Germany, South Korea, Japan, and in the US states of Washington, Oregon, Colorado, Hawaii, Vermont, Montana, Washington DC, and California. [9]

\section{Netherlands}

In April 2002, the Netherlands became the first country to legalize euthanasia and assisted suicide. It imposed a strict set of conditions: the patient must be suffering unbearable pain, their illness must be incurable, and the demand must be made in "full consciousness" by the patient. In 2010, 3,136 people were given a lethal cocktail under medical supervision. So-called palliative sedation has also become a widespread practice in hospitals, with 15,000 cases a year since 2005, according to the Royal Dutch Medical Association. Patients with a life expectancy of two weeks or less are put in a medically induced coma, and all nutrition and hydration is withdrawn. 


\section{France}

Euthanasia and assisted suicide are against the law. The president, François Hollande, promised to look at the "right to die with dignity" but has always denied any intention of legalising euthanasia or assisted suicide. In 2005 the Léonetti law introduced the concept of the right to be "left to die". Under strict conditions it allowed doctors to decide to "limit or stop any treatment that is not useful, is disproportionate or has no other object than to artificially prolong life" and to use pain-killing drugs that might "as a side effect, shorten life".

\section{United States}

Doctors are allowed to prescribe lethal doses of medicine to terminally ill patients in five US states. Euthanasia, however, is illegal. Oregon was the first US state to legalise assisted suicide. The law took effect in 1997, and allows for terminally ill, mentally competent patients with less than six months to live to request a prescription for life-ending medication. More than a decade later, Washington state approved a measure .And last year, the Vermont legislature passed a similar law. Court decisions rendered the practice legal in Montana and, most recently, in New Mexico. In 2013, roughly 300 terminally ill Americans were prescribed lethal medications, and around 230 people died as a result of taking them. Some patients choose not to take the medication.

\section{Germany and Switzerland}

In German-speaking countries, the term "euthanasia" is generally avoided because of its association with the eugenicist policies of the Nazi era. The law therefore tends to distinguish between assisted suicide (beihilfezumsuizid) and "active assisted suicide" (aktivesterbehilfe). In Germany and Switzerland, active assisted suicide - i.e., a doctor prescribing and handing over a lethal drug - is illegal. But German and Swiss law does allow assisted suicide within certain circumstances. In Germany, assisted suicide is legal as long as the lethal drug is taken without any help, such as someone guiding or supporting the patient's hand. In Switzerland, the law is more relaxed: it allows assisted suicide as long as there are no "self-seeking motives" involved. Switzerland has tolerated the creation of organisations such as Dignitas and Exit, which provide assisted dying services for a fee.

\section{Belgium}

Belgium passed a law in 2002 legalising euthanasia, becoming the second country in the world to do so. The law says doctors can help patients to end their lives when they freely express a wish to die because they are suffering intractable and unbearable pain. Patients can also receive euthanasia if they have clearly stated it before entering a coma or similar vegetative state. [10] Advanced Directive (AD) is legally valid and enforceable in the USA [11] Canada, Australia and many countries across Europe. [12] ADs have been endorsed by the United Nations Convention on the Rights of Persons with Disabilities. [13] Whereas half of the Americans have ADs, the concept is unknown by many in India. [14] Australian Scientist Dr. David Gudall,104 years old, was born British but lived in Australia. At the end of his life, he flew to Switzerland for assisted suicide. He fought to die on his terms because of his deteriorating health. Since active euthanasia or assisted suicide is not legalised in Australia, he had to leave his country to die with dignity. [15]

\section{Passive euthanasia, Active euthanasia \& the Law in India}

Passive Euthanasia Now a Legal Reality in India. Recognising "living wills" made by terminallyill patients, the Supreme Court has held that the right to die with dignity is a fundamental right. Declaring the right to die with dignity as a fundamental right, the Supreme Court in a landmark judgment on 7 March 2018 passed an order allowing passive euthanasia in the country. [16] The apex court has said that an individual could make an advance "living will" that would authorize passive euthanasia under certain circumstances. Delivering the judgment, Justice Chandrachud 
said, "Life and death are inseparable. Every moment our bodies undergo change... life is not disconnected from death. Dying is a part of the process of living." [17]

A Constitution Bench, led by Chief Justice of India Dipak Misra, in three concurring opinions, upheld that the fundamental right to life and dignity includes right to refuse treatment and die with dignity. [18] It can be done by means of the withdrawal of life support to patients in a permanent vegetative state. The decision was made as part of the verdict in a case involving Aruna Shanbaug, who had been in a Persistent Vegetative State (PVS) until her death in 2015.

This judgment was passed in wake of Pinki Virani's plea to the highest court in December 2009 under the Constitutional provision of "Next Friend". It's a landmark law which places the power of choice in the hands of the individual, over government, medical or religious control which sees all suffering as "destiny". The Supreme Court specified two irreversible conditions to permit Passive Euthanasia Law in its 2011 Law: (I) The brain-dead for whom the ventilator can be switched off (II) Those in a Persistent Vegetative State (PVS) for whom the feed can be tapered out and pain-managing palliatives be added, according to laid-down international specifications. The same judgement-law also asked for the scrapping of 309, the code which penalises those who survive suicide-attempts. In December 2014, government of India declared its intention to do so. [19]

Response from different religious leaders were in accordance with their religious scriptures. Christians and the Jains thought passive euthanasia was acceptable under some circumstances [20]. Jains and Hindus have the traditional rituals Santhara and Prayopavesa respectively, wherein one fasts unto death. The Jain vow of santhara, is observed by the Jains only in special circumstances. These are mentioned in the Jain texts. [21] Some members of India's medical establishment were skeptical about euthanasia due to the country's weak rule of law and the large gap between the rich and the poor, which might lead to the exploitation of the elderly by their families. [22] It was observed that the issue was not considered politically contentious in India." [23]

\section{Frequently Asked Questions on Living Will}

\section{Who can make a Living Will ?}

An adult with a sound and healthy mind can make a living will. It should be voluntarily executed and based on informed consent. It should be expressed in specific terms in a language "absolutely clear and unambiguous".

\section{What it should contain?}

It should contain the circumstances in which medical treatment should be withheld or withdrawn. It should specify that, the living will can be revoked any time.

\section{How to Create a Living Will}

People can hire a lawyer to prepare their living will. If you need to write or update a will or trust, you can take care of your living will at the same time. You can create a legally binding health care directive (living will) without paying an attorney by using reputable estate planning software, like Nolo's award winning Will Maker Plus. It should give the name of the "guardian or close r elative" who will give the go-ahead for starting the procedure of passive euthanasia. If there are more than one Living Will, the latest one will be valid.

\section{How to preserve it?}

The Will shall be attested by two independent witnesses and preferably counter-signed by the Judicial Magistrate First Class (JMFC) assigned the jurisdiction by the District Court.The JMFC shall preserve one hard copy, along with one in the digital format, in his office. JMFC shall forward a copy of the Will to the Registry of the District Court JMFC shall inform the immediate family of the executor, if not informed. A copy will be handed over to an official in the local government 
or municipal corporation or municipality or panchayat concerned. This authority shall nominate a custodian for the Living Will. [24]

\section{Conclusions}

It is a great victory for the patients who are terminally ill or on palliative care or vegetative to end their sufferings. It is inhuman to allow someone to die. At the same time, it is inhuman to see someone suffering terribly. We have to take the call as per the basic human rights of living with dignity and patients' autonomy that is living will.

\section{REFERENCES}

1. Legalzoom.com. (2018). What Is a Living Will?. [online] Available at: https://www.legalzoom.com/knowledge/living-will/topic/what-is-a-living-will [Accessed 1 Oct. 2018].

2. Ghooi RB, Dhru K, Jaywant S. The urgent need for advance directives in India. Indian journal of medical ethics. 2016;1(4):242-9.

3. Rocketlawyer.com. (2018). Living Will vs. Last Will and Testament | Rocket Lawyer. [online] Available at: https://www.rocketlawyer.com/article/living-will-vs-last-will-and-testament.rl [Accessed 1 Oct. 2018].

4. Bbc.co.uk. (2018). BBC - Ethics - Euthanasia: Active and passive euthanasia. [online] Available at: http://www.bbc.co.uk/ethics/euthanasia/overview/activepassive_1.shtml [Accessed 1 Oct. 2018].

5. Pregnantpause.org. (2018). Euthanasia. [online] Available at: http://www.pregnantpause.org/euth/index.html [Accessed 1 Oct. 2018].

6. India, T., verdict, A., attack, T., coma, L., Valmiki, W., opposition, F. and peace, F. (2018). Euthanasia: The Aruna Shanbaug case which changed euthanasia laws in India. [online] The Economic Times. Available at: https://economictimes.indiatimes.com/news/politics-andnation/the-aruna-shanbaug-case-which-changed-euthanasia-laws-in-india/a-landmarkverdict/slideshow/63231071.cms

7. The Guardian. (2018). Euthanasia and assisted suicide laws around the world. [online] Available at: https://www.theguardian.com/society/2014/jul/17/euthanasia-assisted-suicide-laws-world [Accessed 1 Oct. 2018].

8. Barta H, Kalchschmid G. Die "Patientenverfügung" in Europa. Wiener Klinische Wochenschrift. 2004 Jul 1;116(13):442-57.

9. Sperrin Á. Independent living for adults with intellectual disabilities in post conflict countries. A comparative analysis of the implementation of Article 19 of the United Nations Convention on the Rights of Persons with Disabilities in Northern Ireland and Bosnia Herzegovina (Doctoral dissertation, NUI Galway).

Acknowledgements - Nil

Source of Funding - Nil

Conflict of Interest - Nil 